\title{
Mucous Cell Types in the Major and Minor Salivary Glands of the Japanese Macaque
}

\author{
By \\ Masatake IMAI, Taizo SHIBATA and Keiichi MORIGUCHI \\ Department of Anatomy, Kanazawa Medical University, Uchinada-machi, \\ Kahoku-gun, Ishikawa 920-02, Japan
}

-Received for Publication, October 30, 1985

Key Words: Mucous cell ty pes, salivary glands, complex carbohydrate, Japanese macaque

Summary. The authors investigated mucous cells in the major and minor salivary glands of the Japanese macaque and concluded the following:

1. Submandibular gland: The mucous acini of this gland are of type II (containing neutral and weak acid mucopolysaccharides).

2. Sublingual gland: The mucous acini of this gland are composed of two types, with type II outnumbering type I (containing neutral, weak and strong acid mucopolysaccharides).

3. Minor sublingual glands: The mucous components of this gland include two types, with type I greatly outnumbering type II.

4. Upper, lower labial, buccal and palatine glands: All of the mucous acini of these glands are of type I.

5. Retromolar glands: The mucous acini definitely surpass the seromucous ones in number, and type I greatly outnumbers type II.

6. Glands in the root of the tongue: The mucous components of these glands include two types, with type I greatly outnumbering type II.

7. Mucous glands neighboring the glands of von Ebner: These glands are composed of two types, and both types almost equal in number.

Imai et al. ${ }^{1)}$ found two kinds of mucous cells in the mucous glands neighboring von Ebner's glands, but did not observe these varieties of mucous cells in other salivary glands of the Japanese macaque. Later they discovered the same cells in the sublingual and minor sublingual glands of the Japanese macaque and humans. ${ }^{2)}$ Moreover, they performed detailed carbohydrate histochemistry on those cells. ${ }^{3)}$

Through this study, the authors have tried to clarify the kinds of mucous cells in the major and minor salivary glands.

\section{Materials and Methods}

Tree adult Japanese macaques were used in this study. The animals were killed by a rapid intravenous injection of about 1.5 cc Nembutal. Samples were taken in as fresh a state as possible and fixed in buffered formalin. The tissues were embedded in paraffin and cut into sections of about $6 \mu$ in thickness. A.B. (pH 2.5, 1.0 and 0.5) stain, Sugiyama's neutral red method, the LID-A. B. (pH 2.5) and HID-A.B. (pH 2.5) methods were used. A.B. (pH 1.0 and 0.5) and neutral red methods are suitable for demonstrating the presence of strong acid muco- 
polysaccharide. Type I mucous cells contain the same mucosubstance, whereas type II mucous cells have no such substance. The LID-A.B. (pH 2.5) and HID-A.B. (pH 2.5) methods can demonstrate, respectively, the presence of weak and strong acid mucopolysaccharides. Thus the type of mucous cell can be determined according to the reactions of the above techniques. A.B. $(\mathrm{pH}$ 2.5 ) reacts to weak acid mucopolysaccharide as well as to strong acid mucopolysaccharide. However, the reaction in type I mucous cells is stronger than that in type II cells.

\section{Observations}

The numeral 1 in the photomicrographs indicates type I mucous cells, and 2 indicates type II.

1. Submandibular gland. All mucous cells were of type II, namely, they reacted negatively to A.B. (pH 1.0) (Figs. 1, 2).

2. Sublingual gland. The mucous cells in this gland consisted of two types, with type II outnumbering type I (Figs. 3, 4, 5).

3. Minor sublingual glands: Formerly, these glands were called the minor sublingual gland. However, Imai et $\mathrm{al}^{2}{ }^{2}$ ) have made clarified their true structure. They found that the gland is composed of many small independent glands that have their own excretory ducts. Each gland was a mixed gland, and its mucous cells greatly outnumbered the seromucous cells. The mucous cells included two kinds, and type I greatly out numbered type II (Figs. 6, 7, 8).

4. Mucous glands neighboring the glands of von Ebner: These were composed of two kinds of mucous cells, which were almost equal in number (Figs. 9, 10, 11, 12).

5. Retromolar glands. These are small independent glands that have their own excretory duct. Each gland was mixed, how- ever, the mucous acini greatly outnumbered the seromucous ones. The mucous acini were composed of two kinds of mucous cells, and type I definitely surpassed type II in number (Figs. 13, 14, 15).

6. Upper, lower labial and buccal glands: These are mixed glands, and mucous and seromucous acini were almost equal in number or the mucous acini slightly surpassed the seromucous ones in number. The mucous acini were type I (Figs. 16 24).

7. Palatine glands. These are mucous glands, and the glandular cells were composed of type I (Figs. 25, 26, 27).

8. Glands in the root of tongue: These are mucous glands, and two types of mucous cells were observed. However, type I greatly outnumbered type II (Figs. 28, 29, 30).

Incidentally, the anterior lingual gland (Gland of Blandin or Nuhn) is absent in the Japanese macaque.

\section{Discussion}

The major and minor salivary glands were found to be composed of one or two kinds of mucous cells, and various combinations of the types were observed.

1. Submandibular gland: All of the mucous cells in this gland were of type II.

2. Sublingual gland: The mucous acini in this gland were composed of two kinds of cell, with type II outnumbering type I.

3. Minor sublingual glands: Type I greatly outnumbered type II.

4. Upper, lower labial, buccal and palatine glands: Only type I mucous cells were observed. Even if type II cells exist, the authors presume that they are few.

5. Retromolar glands: Two types were observed, however, type I predominated over 
type II.

6. Glands in the root of the tongue: These were composed of two kinds of mucous cells, and type I greatly outnumbered type II.

7. Mucous glands neighboring von Ebner's glands: These were composed of two types of mucous cells, with both types almost equal in number.

From the above description, it is quite clear that type I mucous cells in the salivary glands predominate over type II. In other words, strong acid mucopolysaccharides in the salivary glands surpass weak acid ones in secretory activity.

Based on data from a previous study, ${ }^{21}$ the authors presume that the kinds of mucous cell in the major and minor salivary glands in humans are probably the same as those in the macaque.

Previously, the authors relied mainly on A.B. stain to determine mucous cell type. However, the LID-A.B. (pH 2.5) and HID-A.B. (pH 2.5) methods are well suited to this purpose.

\section{References}

1) Imai, M., Shibata, T. and Higashi, N.: Structure and carbohydrate histochemistry of the minor salivary glands of the Japanese macaque (Macaca fuscata yakui). Okajimas Fol. Anat. Jap., 58: 485-499, 1982.

2) Imai, M., Shibata, T. and Shimano, J.: An opinion on the minor sublingual gland. Okajimas Fol. Anat. Jap., 58: 635-647, 1982.

3) Imai, M., Shibata,T., Moriguchi, K. and Sakai, J.: Mucous cell types. Okajimas Fol. Anat. Jap., 63: 365-369, 1986. 


\section{Explanation of Figures}

\section{Plate I}

Submandibular, sublingual, minor sublingual glands, mucous gland neighboring the glands of von Ebner and retromolar gland of the Japanese macaque.

The numeral 1 in the figures indicates ty pe I mucous cells, and 2 indicates type II.

Fig. 1. Submandibular gland. A.B. $(\mathrm{pH} 2.5)$ stain. $\times 300$

2: Type II. Weak reaction to A.B. (pH 2.5).

Fig. 2. The same gland as in Fig. 1. A.B. $(\mathrm{pH} 1.0) \times 300$

2: Type II. Negative reaction to A.B. $(\mathrm{pH} 1.0)$.

Fig. 3. Sublingual gland. A.B. (pH 2.5) stain. $\times 300$

1: Type I. Fair strong reaction to A.B. (pH 2.5). 2: Type II. Weak reaction to A.B. (pH 2.5).

Fig. 4. The same gland as in Fig. 3. A.B. $(\mathrm{pH} 0.5)$ stain. $\times 300$

1: Type I. Strong reaction to A.B. (pH 0.5). 2: Tye II. Negative reaction to A.B. (pH 0.5).

Fig. 5. The same gland as in Fig. 3. HID-A.B. (pH 2.5) method. $\times 300$

1: Type I. Reaction color : Violet black. 2: Type II. Reaction color : Blue.

Fig. 6. Minor sublingual gland. A.B. (pH 2.5) stain. $\times 300$

1: Type I. Strong reaction to A.B. ( $\mathrm{pH} \mathrm{2.5).} \mathrm{Type} \mathrm{II} \mathrm{is} \mathrm{absent} \mathrm{in} \mathrm{this} \mathrm{figure.}$

Fig. 7. The same gland as in Fig. 6. A.B. $(\mathrm{pH} 0.5)$ stain. $\times 300$

1: Thpe I. Strong reaction to A.B. (pH 0.5). 2: Type II. Negative reaction to A.B. (pH 0.5).

Fig. 8. The same gland as in Fig. 6. HID-A.B. (pH 2.5) method. $\times 300$

1: Type I. Reaction color : Violet black. 2: Type II. Reaction color : Blue.

Fig. 9. Mucous gland neighboring von Ebner's gland. A.B. (pH 2.5) stain. $\times 300$

1: Type I. Fairly strong reaction to A.B. (pH 2.5).

2: Type II. Weak reaction to A.B. ( $\mathrm{pH} \mathrm{2.5).}$

Fig. 10. The same gland as in Fig. 9. A.B. $(\mathrm{pH} 0.5)$ stain. $\times 300$

1: Type I. Weak reaction to A.B. (pH 0.5). 2: Type II. Negative reaction to A.B. (pH 0.5 ).

Fig. 11. The same gland as in Fig. 9. LID-A.B. (pH 2.5) method. $\times 300$

1: Type I. Reaction color : Violet black. 2: Type II. Reaction color : Blue.

Fig. 12. The same gland as in Fig. 9. HID-A.B. (pH 2.5) method. $\times 150$

1: Type I. Reaction color : Violet black. 2: Type II. Reaction color : Blue.

Fig. 13. Retromolar gland. A.B. (pH 2.5). $\times 300$

1: Type I. Strong reaction to A.B. (pH 2.5). No type II in this Fig.

Fig. 14. The same gland as in Fig. 13. A.B. (pH 0.5) stain. $\times 300$

1: Type I. Fairly strong reaction to A.B. ( $\mathrm{pH} 0.5$ ). Thpe II is absent in this Fig.

Fig. 15. The same gland as in Fig. 13. HID-A.B. (pH 2.5) method. $\times 300$

1: Type I. Reaction color : Violet black. Ty pe II is absent in this Fig. 
Plate I

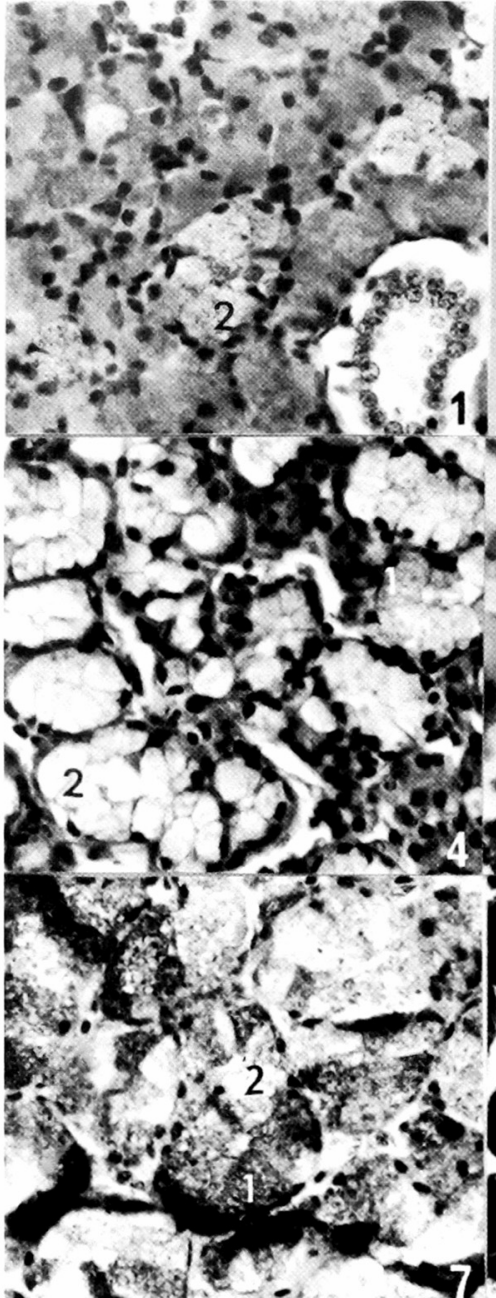

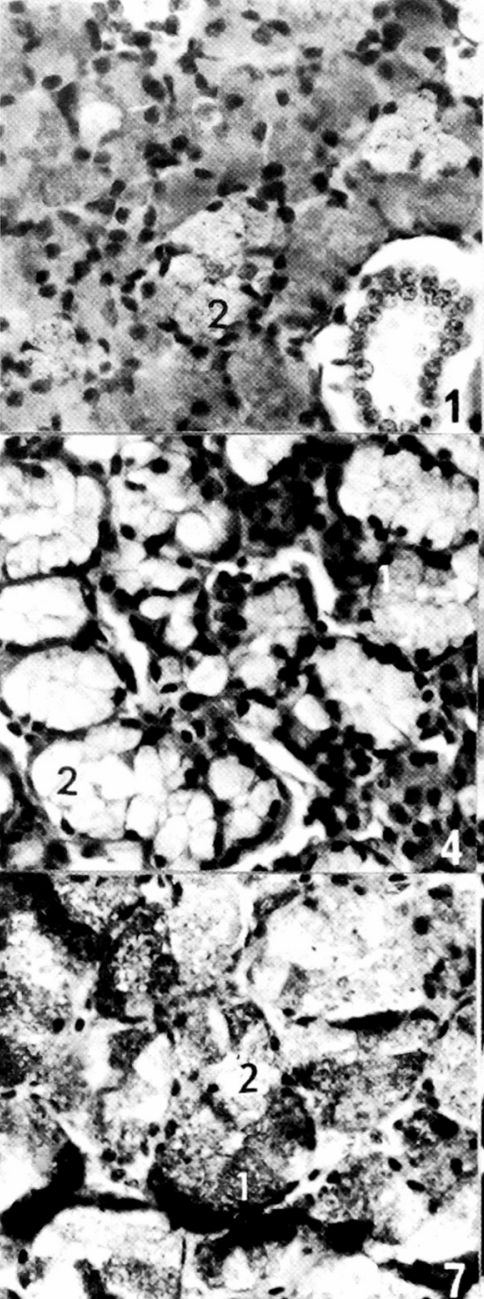

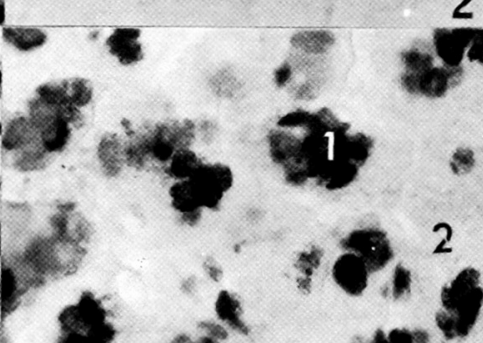
r.

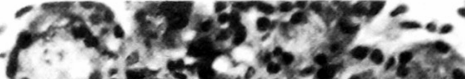

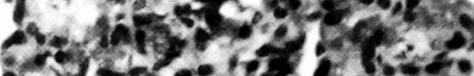

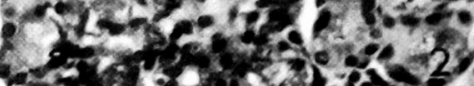

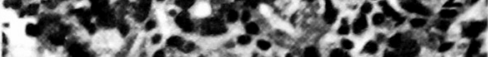

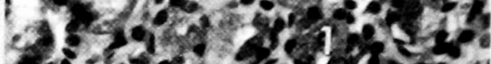

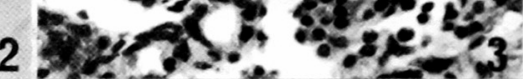
$5.21 x^{2}+a n-5$
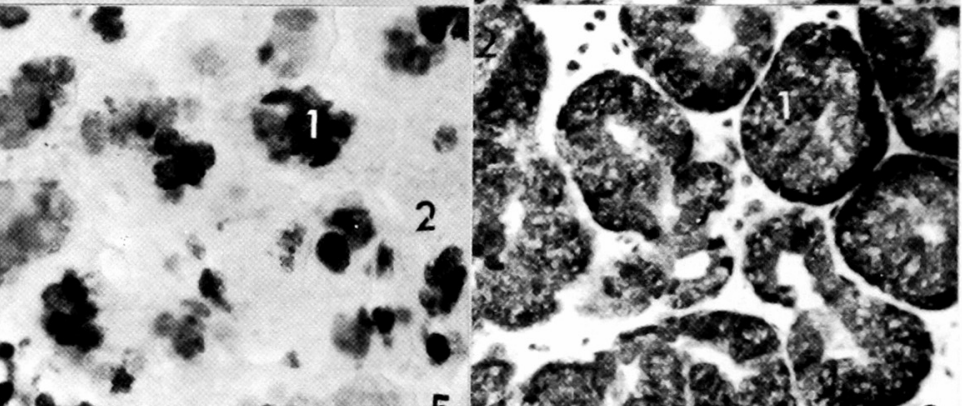

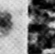

cos 12

- 3.5

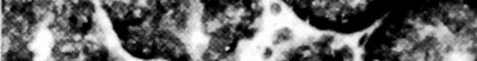

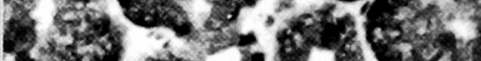

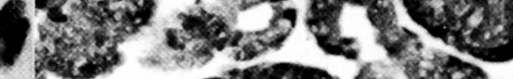

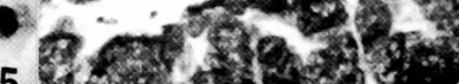

5 of 3 .

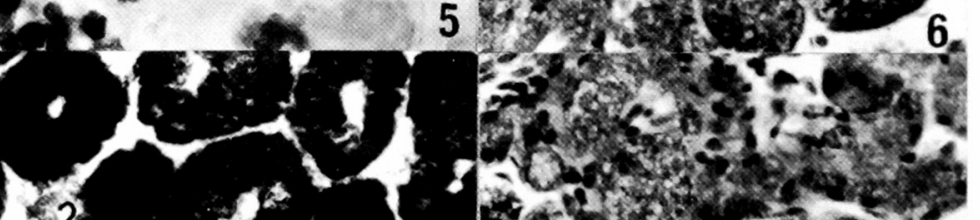

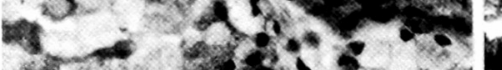
tration on

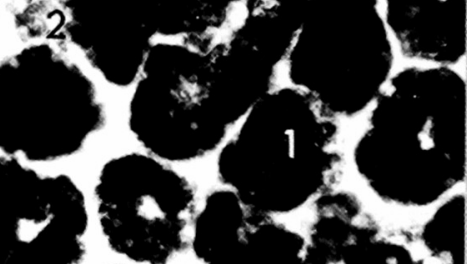
$3 x+1, x$ ?

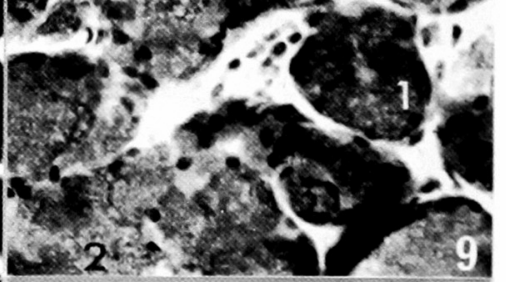

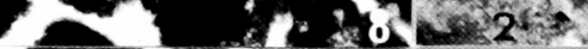
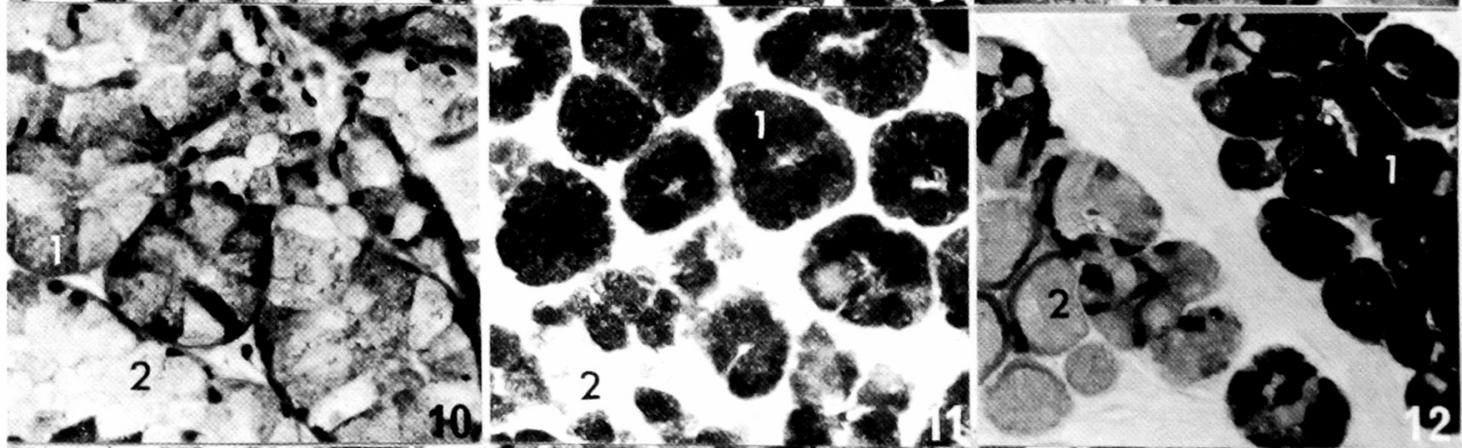

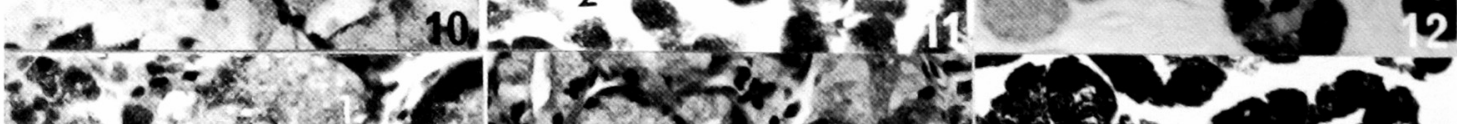

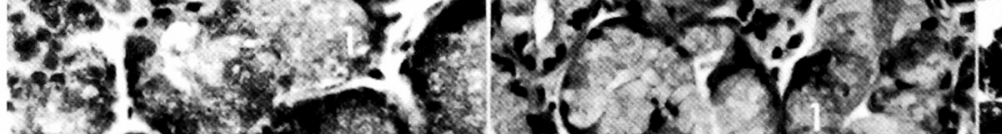

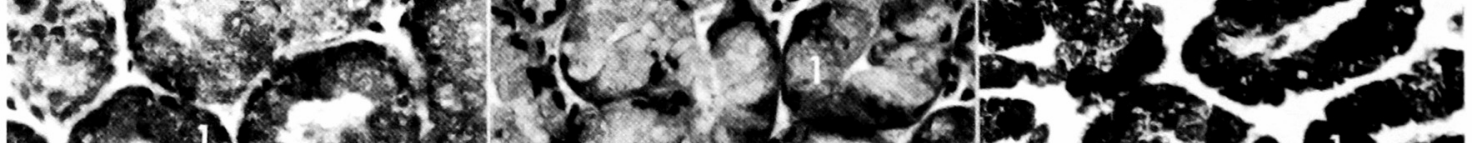

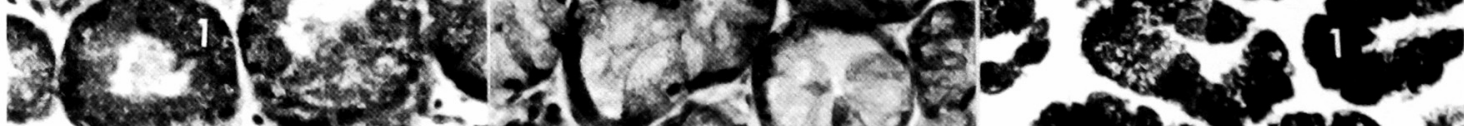

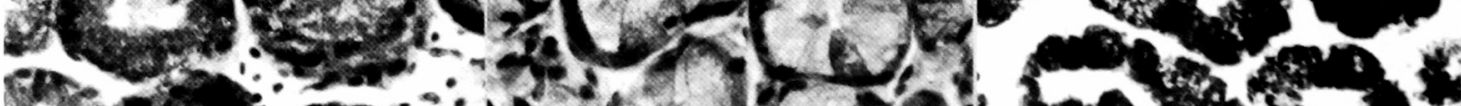

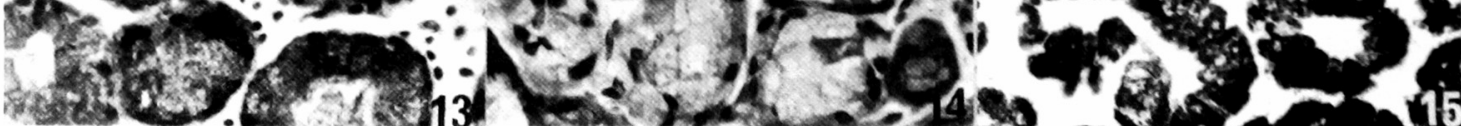




\section{Plate II}

Upper, lower labial, buccal, palatine glands and glands in the root of the tongue of the Japanese macaque. The numeral 1 in the figures indicates type I mucous cells, and 2 indicates type II.

Fig. 16. Upper labial gland. A.B. $(\mathrm{pH} 2.5)$ stain. $\times 300$

1: Type I. Strong reaction to A.B. ( $\mathrm{pH} 2.5$ ). Type II is absent.

Fig. 17. The same gland as in Fig. 16. A.B. $(\mathrm{pH} 0.5)$ stain. $\times 300$

1: Type I. Fairly strong reaction to A.B. (pH 0.5). Type II is absent.

Fig. 18. The same gland as in Fig. 16. HID-A.B. $(\mathrm{pH} 2.5)$ method. $\times 300$

1: Type I. Reaction color : Violet black. Type II is absent.

Fig. 19. Lower labial gland. A.B. $(\mathrm{pH} 2.5)$ stain. $\times 300$

1: Type I. Strong reaction to A.B. $(\mathrm{pH} 2.5)$. Type II is absent.

Fig. 20. The same gland as in Fig. 19. A.B. $(\mathrm{pH} 0.5)$ stain. $\times 300$

1: Type I. Fairly strong reaction to A.B. (pH 0.5$)$. Type II is absent.

Fig. 21. The same gland as in Fig. 19. HID-A.B. $(\mathrm{pH} 2.5)$ method. $\times 300$

1: Type I. Reaction color : Violet black. Type II is absent.

Fig. 22. Buccal gland. A.B. $(\mathrm{pH} 2.5)$ stain. $\times 300$

1: Type I. Strong reaction to A.B. (pH 2.5). Type II is absent.

Fig. 23. The same gland as in Fig. 22. A.B. (pH 0.5) stain. $\times 300$

1: Type I. Strong reaction to A.B. (pH 0.5). Type II is absent.

Fig. 24. The same gland as in Fig. 22. HID-A.B. $(\mathrm{pH} \mathrm{2.5)} \mathrm{method.} \times 300$

1: Type I. Reaction color : Violet black. Type II is absent.

Fig. 25. Palatine gland. A.B. $(\mathrm{pH} 2.5)$ stain. $\times 300$

1: Type I. Fairly strong reaction to A.B. (pH 2.5). Type II is absent.

Fig. 26. The same gland as in Fig 25. A.B. ( $\mathrm{pH} 0.5)$ stain. $\times 300$

1: Type I. Fairly strong reaction to A.B. (pH 0.5$)$. Type II is absent.

Fig. 27. The same gland as in Fig. 25. HID-A.B. $(\mathrm{pH} \mathrm{2.5)}$ method. $\times 300$

1: Type I. Reaction color : Violet black. Type II is absent.

Fig. 28. Gland in the root of tongue. A.B. $(\mathrm{pH} 2.5)$ stain. $\times 300$

1: Type I. Fairly strong reaction to A.B. (pH 2.5$)$. Type II is absent in this Fig.

Fig. 29. The same gland as in Fig. 28. A.B. $(\mathrm{pH} \mathrm{0.5)} \mathrm{stain.} \times 300$

1: Type I. Fairly strong reaction to A.B. (pH 0.5$)$.

2: Type II. Negative reaction to A.B. ( $\mathrm{pH} 0.5)$.

Fig. 30. The same gland as in Fig. 28. HID-A.B. $(\mathrm{pH} 2.5)$ method. $\times 300$

1: Type I. Reaction color : Violet black.

2: Type II. Reaction color : Blue. 
Plate 2

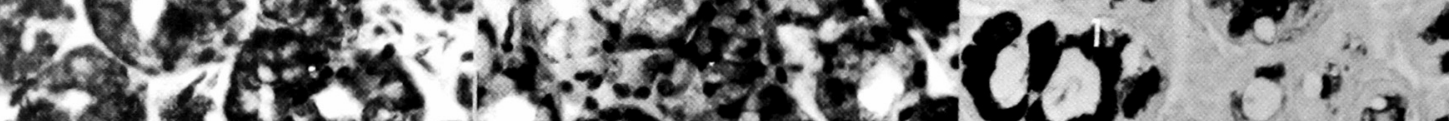

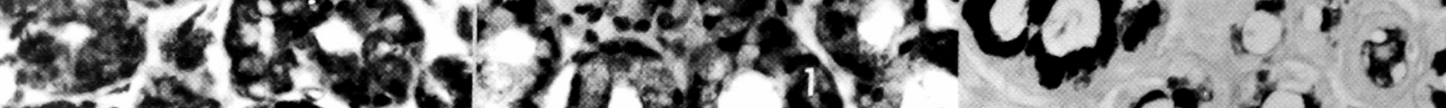

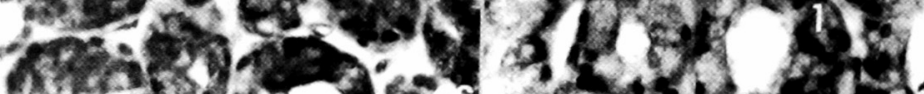

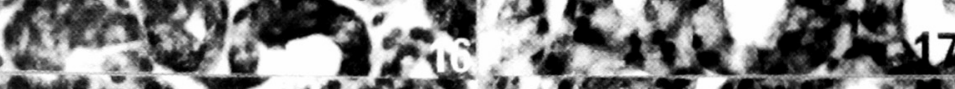

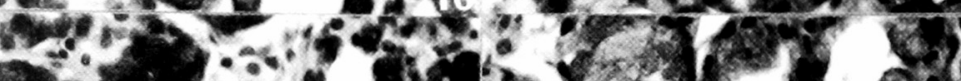

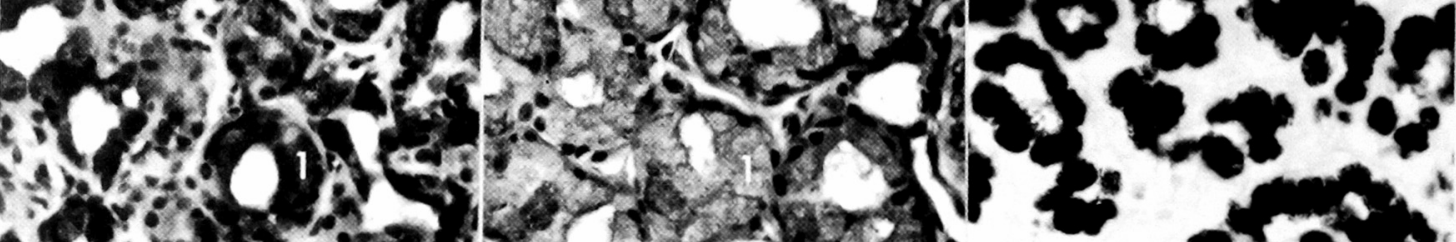

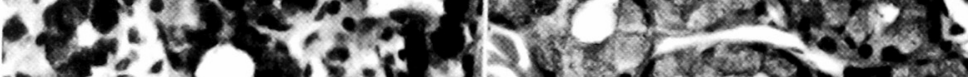

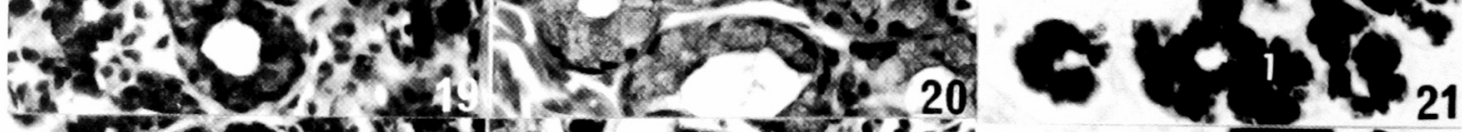

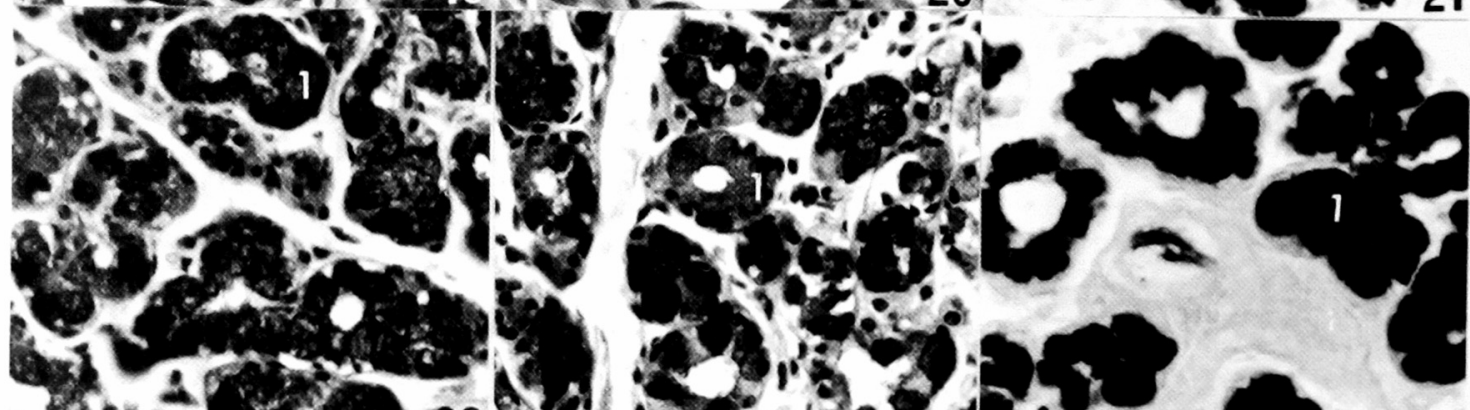
26.

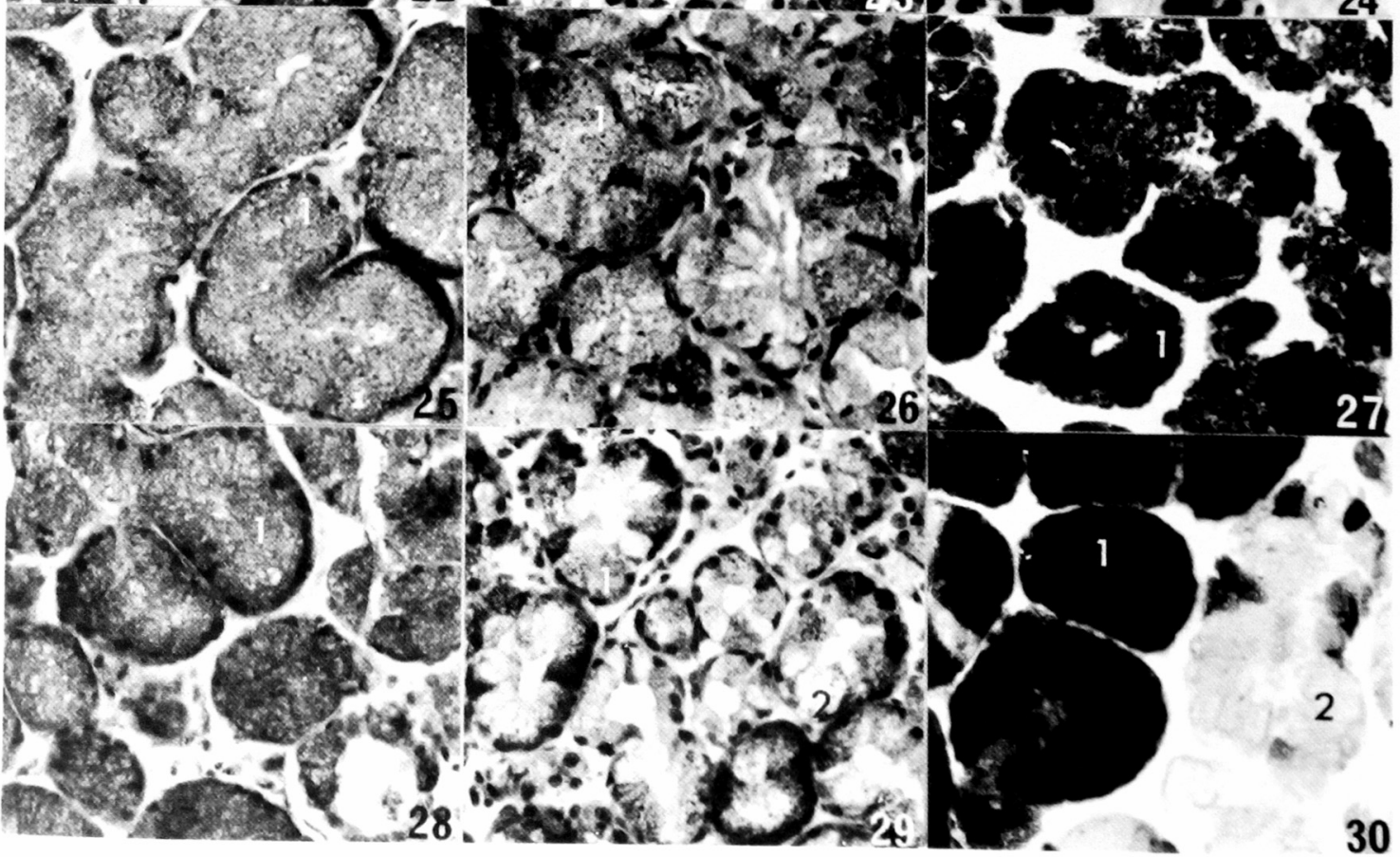

